\title{
STUDENT'S GAINS OF DEBATING IN THE PRODUCTIVE LEARNING PROCESS
}

\author{
Alīda Samuseviča \\ Liepājas Universitāte, Latvija \\ Maija Ročāne \\ Liepājas Universitāte, Latvija
}

\begin{abstract}
Publication highlights pedagogical possibilities of gaining transversal competences through debating process. Productive learning process has been described and data have gathered in order to identify the results of productive learning through debating. The necessity of productive learning has been emphasized in the context of key competencies and learning outcomes-based education approach as in the 21st century students need not only to take the initiative, understand the needs, formulate objectives, identify learning strategies, evaluate their learning achievements but also to explore a set of information offered by the information society which must be transformed into the knowledge society. The publication reflects the results of the case study, which emphasize obtaining the transversal skills through debating.

Keywords: debating, freedom of cognition, student, productive learning, transversal competences.
\end{abstract}

\section{Introduction}

Learning starts with the individual's set of knowledge and skills and understanding of integrity and effectiveness of learning realization. Each student demonstrates his/her individual learning style in the learning process through obtaining new facts, being aware of new needs and creating a new holistic understanding, creating knowledge and producing emotions. Learning outcomes are reflected and tested in a real life as well as new goals are set and beliefs are strengthed. However, it must be admitted that the curriculum changes have created new challenges in Europe. "The key competencies and learning outcomesbased education approaches that make up the content of education in the largest part of Europe also imply important changes in the form of teaching" (European Commission, 2012, 25). Therefore, it is essential for the teacher to guide students through the learning process in which students become independent, ready to take the initiative to understand the needs, formulate objectives, identify learning strategies, evaluate their learning achievements (Savin-Baden \& Major, 2004). 
Alìda Samuseviča, Maija Ročāne. Student`s gains of debating in the productive learning process

The potential of digital age is the ability to influence the learning process through providing students unlimited access to information and the ability to direct their learning process (Fullan \& Langworthy, 2014). Information society has gained its topicality and importance in the learning process in the 21 st century; however, it must be acknowledged that only the knowledge society holds wide range of social, ethical and political dimensions (Latvijas Republikas Izglitīibas un zinātnes ministrija, 2013).

The provision of free flow of ideas (information society) and the circulation of knowledge (knowledge society) have been mentioned in the articles of the United Nations Educational, Scientific and Cultural Organization (UNESCO). The organization has specifically addressed the issues of information and knowledge management in 1990. However, the UNESCO research (2005) "Towards a knowledge-based society" has emphasized the need to move from the information-based society to knowledge-based society, which can be characterized by knowledge, analysis, improvement, distribution, development and application. And the only significant contribution of the information-based society is a direct input into the process of formation of the knowledge-based society. Thus, the information-based society is becoming a very important prerequisite for the process of formation of a knowledge-based society. However, the question is how to direct the learning process in the conditions of information society? (UNESCO, 2005).

Defining learning Zull, J. E. (2004), Oganisjana, K. (2015), Atkinson et al. (1993) have highlighted changes caused by it. Educator, biologist and biochemist James Zull believes that "when we are learning, we are changing. We learn to do something new, or learn to do something better or stop doing something at all. Learning definitely generates changes. Changes may be invisible and may be considerable. Learning can also lead to complete change of life" (Zull, 2004, 68). Researcher Karine Oganisjana (2015) also highlights that in the process of learning "people change" (Oganisjana, 2015). The educational psychologist Ferenc Marton and pedagogical researcher Shirley Booth (1997) believes that learning takes place in the individual's perception and development of understanding of the world (Marton \& Booth, 2009). It is also important to respect each student's uniqueness, individual learning style, because "the world reveals differently to each of us" (Marton \& Booth, 2009, 1).

However, it must be admitted that learning starts with the identification of a problem (in the society, science, etc.), strategy development follows, identifying the problem, selecting resources and involving classmates in the problem solving process (Martin-Kniep \& Picone-Zocchia, 2009). Emphasizing the necessity of the development of individual learning style or strategy, the authors of the publication are willing to emphasize the importance of productive or resultoriented learning, which includes a number of important factors, e.g. linking the 
knowledge with a real life, student's responsibility for the learning process, the awareness of a freedom of cognition, the positive emotional environment, motivation, beliefs, awareness of goals, productive learning promoting methods within and outside the classroom. It must be admitted that the result of productive learning is not only obtaining the key competencies defined by the European Commission (Key Data on Education in Europe, 2012) but also transversal competences.

The goal of the article is to justify the pedagogical factors of the formation of transversal competences, identifying student's learning gains in the productive learning process through debating.

\section{The contributing factors of the productive learning process}

There is a topical view that the learning process must be transformed, however, the question is: what exactly should be changed and how to change it? And one of the crucial key factors in the process of the development of the knowledge-based society is freedom. Freedom can be manifested through freedom of expressing opinion orally and in written form; freedom of press, freedom to access the information, as well as freedom of dissemination of information, etc. It is also essential in the process of information transformation into knowledge, which occurs through discussions, analysis, scientific activities, etc. (UNESCO, 2005). Thus, the freedom of cognition becomes a key factor in the knowledge acquisition process, which occurs when student explores information and transforms it into the knowledge. As a result of this learning process not only the student changes, but also he/she gives a contribution to the knowledge society.

To promote productive learning, it is important to be tolerant towards the others, to accept the diversity of opinions, thus respecting human freedom and the interests of all the society (UNESCO, 2005). It must be admitted that "if the concept of freedom in the past has been most commonly associated with the fight against injustice, nowadays the understanding of freedom is based on justice and individual freedom" (Bookchin, 1982, 168). Freedom is often associated with the freedom of choice: "to do something" or "do nothing and stand aside" (O Connor, 2005, 7-8). Thus, the free will gains its significance. Philosopher and theologian Jonathan Edwards in his work "The freedom of the will" (1754) emphasizes both the freedom of action and denial, as well as the factor of free will. Here recognition and non-recognition, liking and dislike, permission and prohibition gains importance (Edwards, 2007). He highlights that free will is determined by motives and needs. The strongest motives are moral needs, responsibility for himself/herself and society or, on the contrary, contrasting ones interests against the interests of the whole society. He also stresses the possibility of a moral failure, which may be permanent or temporary (Edwards, 2007). Emphasizing the 
link between the necessity and the free will, it is important to link the learning process with a real life.

Philosopher Rudolf Steiner in his work "Philosophy of Freedom" names motives as the main driving force of the free will. He also expresses belief that the person is free as much as he/she is able to obey himself/herself (Steiner, 1918). Educational researchers Maggi Savin-Baden and Claire Major believe that to implement a successful learning process, student must be motivated (SavinBaden \& Major, 2004).

Motivation clearly ensures the obtaining of both knowledge and skills. Student's motivation can be contributed by:

1. "student's understanding of the application of knowledge;

2. awareness of goals;

3. student's belief;

4. the individual set of values;

5. a positive attitude towards the subject;

6. learning enhancing environment;

7. positive emotions;

8. availability of resources" (Benavides, Dumont, \& Istance, 2012, 4).

The psychologist Mārtinš Veide believes that the major problem of the lack of motivation in today's school is being unaware of goals: students do not discern "the efficiency of their activities", because they do not have a clear understanding of the usage of knowledge (Veide, 1998, 10). However, it is important to recognize that an important prerequisite for the expression of free will is a factor of responsibility, which manifests in the form of activity, decision-making, etc. (Fisher, 2005). The responsibility can be defined as the consequences of action, determined by the expression of attitude, such as gratitude, or guilt, etc. It sets/drives action (Oshana, 1997). Responsibility is a form of regulating human activity. It is expressed through the attitude towards oneself, others and society as a whole (Тутушкина, 2001).

It can be concluded that motivation, responsibility, awareness of goals and needs (connecting learning process with a real life) are contributory factors of a free will and a freedom of cognition.

\section{Productive learning enhancing environment}

There is unlimited access to information in the 21 st century and the learning environment is not only the classroom or school, but all the society. However, how to build a successful learning process and use all the opportunities offered by the information age? The study of Strategic Analysis Commission's "Information environment of Latvia in the beginning of the 21 st century" (2006) emphasizes the positive contribution of the information environment accessibility to both the 
individual and the society. The study highlights that today's textbooks are only a small part of all everyday information environment or information ecology. The study associates information environment with "the living space". Information environment consists of a set of factors, resources, and also processes, which include both the gained knowledge of individual and all the society" (Brikše, 2006, 8-9).

However, only the presence of information cannot ensure productive learning process, a positive emotional learning environment is also required. Regulation of emotion is highlighted by Benavides, F., Dumont, H., Istance, D. (2012) and Zull, J. E. (2004). Learning causes physical changes in the brain and emotions are important change agents in this process. Therefore, positive emotions evocative learning methods gain significance in the learning process. If the teacher's explanation of the subject matter is monotonous, emotions may not arise at all and therefore, the learning may not occur properly. And even if a student makes a mistake in the knowledge-construction process, these mistakes are also very significant in the learning process (Zull, 2004). The psychologist Kristīne Martinsone (1999) believes that "the more positive is the student's emotional attitude against himself/herself, the more productive his/her learning process is as well as self-improvement work. Positive learning attitude also provides the opportunity to make full use of his/her potential (Martinsone, 1999). However, if the positive emotions encourage students to learn, then the negative can stop the progress of the learning process at all (Benavides, Dumont, \& Istance, 2012).

\section{The formation of student's transversal competences through debating in the productive learning process}

In a rapidly changing world the necessary volume of information and competences is constantly growing, e.g. complex problem solving, teamwork, effective, work with a large amount of information. And there are no correct or incorrect answers provided, students have to create/construct new knowledge, to have the ability to navigate in the global technology environment, etc.

In 2007, the European Parliament has approved the lifelong learning basic competences (European Framework for Key Competences), which are important for personal development, social inclusion, active citizenship and employability in a knowledge society (European Commission, 2007). Competences are described as "a combination of knowledge, skills and attitudes appropriate to the context. Key competences are those which all individuals need for personal fulfilment and development, active citizenship, social inclusion and employment. The Reference Framework sets out eight key competences: 1) communication in the mother tongue; 2) communication in foreign languages; 3) mathematical 
Alīda Samuseviča, Maija Ročāne. Student’s gains of debating in the productive learning process

competence and basic competences in science and technology; 4) digital competence; 5) learning to learn; 6) social and civic competences; 7) sense of initiative and entrepreneurship; 8) cultural awareness and expression" (European Commission, 2007).

It should be recognized that the learning outcomes are closely linked to the performance of students, rather than the teacher's goals and learning outcomes are expressed with knowledge as well as skills and competences' (European Commission, 2012). However, unfortunately, many students cannot use the obtained knowledge and skills, which are gaines in a specific context, in a new real-life situation and therefore "even outstanding students have a barrier to become competent adults" (European Commission, 2007, 16).

It must be recognized that in today's society individual action is one of the main requirements and exactly competence has become a key element of each person's characteristics. In the transition process within education reforms, it is important to offer students relevant information and develop their knowledge. However, more necessary is to teach students to think, to analyse, to act, to take responsibility and to be able to implement their goals. Thus, in parallel with the obtaining of key competences, transversal competences gain importance, which can be applied in diverse real-life situations in today's changing world. "There are different understandings and conceptualizations of transversal skills across countries but in general, transversal skills refer to a number of important competencies that can be learned and that everyone requires to successfully adapt to changes and to lead meaningful and productive lives" (UNESCO, 2015, 3).

The framework of transversal competences includes:

- "Critical and innovative thinking (creativity, entrepreneurship, resourcefulness, application skills, reflective thinking, reasoned decision-making);

- interpersonal skills (communication skills, organizational skills, teamwork, collaboration, sociability, collegiality, empathy, compassion);

- intra-personal skills (self-discipline, ability to learn independently, flexibility and adaptability, self-awareness, perseverance, selfmotivation, compassion, integrity, risk-taking, self-respect);

- global citizenship awareness, tolerance, openness, respect for diversity, intercultural understanding, ability to resolve conflicts, civic/political participation, conflict resolution, respect for the environment);

- media and information literacy (ability to obtain and analyze information through ICT, express ideas through media and ICT, ethical use of ICT)" (UNESCO, 2015, 5). 


\section{Identification of the results of productive learning process through debating}

Herbart's didactic triangle highlighted educational links are: teacher-student; teacher-learning content; student-learning content (Peterssen, 1983). These links are strengthened or reduced by different learning methods and didactic approaches. For example, if the productive learning method, e.g. debating is implemented in the learning process, students are active, explore the learning content themselves and self-realize. Thus teacher`s and student`s interaction leads to student-centred learning process. It must be admitted that implemented learning content through debating is relevant in today's situation, the student's interests and needs and thus acquired knowledge becomes the basis for a new experience. In order to analyse the results of productive learning process through debating, the case study in the National debate tournament of Latvia was carried out. The tournament was organized by the association "Debašu centrs" (Debate Centre) in November 16, 2016, in Iecava.

The tournament was attended by 106 students from various regions of Latvia (Bauska, Cēsis, Daugavpils, Krāslava, Liepaja, Līvāni, Madona, Riga, Vecpiebalga, Ventspils). They represented 16 educational institutions of the Republic of Latvia. There were 102 questionnaires (44 male and 58 female respondents) gathered. 4 questionnaires were not returned. Respondents' average length of debating was 19 months. The average age of respondents was 16 .

Within the questionnaire students were asked to continued unfinished sentence " Since I started debating. I have learnt...". Respondents had possibility to add three gains of debating. The vast majority of respondents- 43 (42.2\%) (20 male 23.female) admitted that they have learned to express their views freely; 21 respondents $(20.6 \%)$ (13 male 8 female) believed that they have gained argumentation skills; 20 respondents (19.6\%) (10 male 10 female) have learned to speak confidently in public; 16 respondents (15.6\%) (7 male, 9 female) have learned to co-operate; $15(14.7 \%)$ respondents highlighted that they have learnt how to spend time positively (emphasizing positive emotions) ( 8 male, 7 female); 15 (14.7\%) (11 female, 4 male) respondents have learned to find the necessary information; 14 (13.7\%) (9 male, 5 female) respondents have become more confident; $12(11.8 \%)$ (5 male, 7 female) respondents have learned to think critically, $12(11.8 \%)$ (6 man., 6 female) respondents have acquired research skills; $11(10.78 \%)$ respondents have acquired knowledge in diverse subjects, 8 (7.84 \%) (6 woman, 2 male) respondents have learnt to listen; 6 (5.88\%) respondents have learned to be tolerant towards the others; $10(9.8 \%)$ respondents have learnt to ask and answer questions; $9(8.82 \%)$ respondents have learnt to analyse; $6(5.88 \%)$ respondents have learnt to think; 4 (3.92\%) respondents have learned to speak; 4 (3.92\%) respondents have learnt to structure; $3(2.94 \%)$ have improved writing skills; $3(2.94 \%)$ respondents have learnt to recognize a 
Alīda Samuseviča, Maija Ročāne. Student’s gains of debating in the productive learning process

problem; 3 (2.94\%) respondents have learned to accept criticism, 2 (1.96\%) respondents have improved foreign languages; 2 (1.96\%) respondents have learned to focus; $1(0.98 \%)$ respondent has learned to improvise; 1 (0.98\%) respondent has learned to learn from mistakes; $1(0.98 \%)$ respondent has learned to encourage; $1(0.98 \%)$ respondent has learned to schedule time. The biggest differences between men and women were found in the acquired listening skills, the ability to find information and argumentation skills.

Another unfinished sentence included in the case study was: "The gains of the process of debating I can apply in real life, because ...". Here the respondents explained how exactly gains described in the previous unfinished sentence can be linked with the real life situations. And the authors of the article could draw conclusions about the development of transversal competences. 53 (51.96\%) respondents have mentioned a variety of every day communication situations (everyday conversations, exchanges of views, formal and informal discussions, etc.), in which they had to "defend their own opinion". 11 (10.78\%) respondents have admitted that they have become more confident about themselves in the reallife situations. $38(37.26 \%)$ respondents believe that the competence acquired through debating can be directly applied to real life situations. They have emphasized that acquired skills can be firmly transferred to real life, e.g., "Debating is about life" or "I can use acquired skills while debating in almost any field ", etc.

After analysing the data gathered in the case study, it can be concluded that the gains acquired while debating corresponds to the framework of transversal competences (see table No. 1).

Table 1 Gains of debating and the framework of transversal competences

\begin{tabular}{|c|c|c|c|c|c|}
\hline $\begin{array}{c}\text { Transversal } \\
\text { competences }\end{array}$ & $\begin{array}{l}\text { Critical and } \\
\text { innovative } \\
\text { thinking }\end{array}$ & $\begin{array}{c}\text { Interpersonal } \\
\text { skills }\end{array}$ & $\begin{array}{l}\text { Intra-personal } \\
\text { skills }\end{array}$ & $\begin{array}{c}\text { Global } \\
\text { Citizenship }\end{array}$ & $\begin{array}{l}\text { Media and } \\
\text { information } \\
\text { literacy }\end{array}$ \\
\hline $\begin{array}{l}\text { The gains } \\
\text { mentioned by } \\
\text { debaters and } \\
\text { the number of } \\
\text { cases }\end{array}$ & $\begin{array}{l}\text { - } \text { argumentation } \\
\text { skills (21) } \\
\text { - thinking } \\
\text { critically (12) } \\
\text { - analysing (9) } \\
\text { - thinking (6) } \\
\text { - improvising (1) }\end{array}$ & \begin{tabular}{|l|} 
- expressing \\
his/her \\
opinion \\
freely (43) \\
- co- \\
operation \\
skills (16) \\
encouraging \\
$(1)$
\end{tabular} & 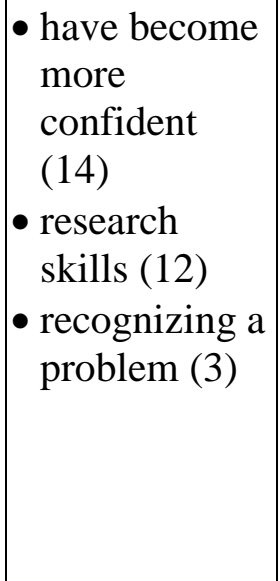 & $\begin{array}{l}\text { - have } \\
\text { learned to } \\
\text { be tolerant } \\
\text { towards the } \\
\text { others (6) } \\
\text { - to accept } \\
\text { criticism (3) }\end{array}$ & $\begin{array}{l}\text { - speaking } \\
\text { confidently } \\
\text { in public (20) } \\
\text { - finding the } \\
\text { necessary } \\
\text { information } \\
\text { (15) } \\
\text { - have learnt to } \\
\text { ask and } \\
\text { answer } \\
\text { questions } \\
\text { (10) }\end{array}$ \\
\hline
\end{tabular}


The authors of the research can conclude that the important gain of the learning method debating is acquiring transversal skills.

\section{Conclusions}

1. Productive learning can be characterized by individual's necessity and freedom of cognition, as well as motivation and behaviour, free will and responsibility. Productive learning is a process where personally significant information transforms into knowledge.

2. The result of productive learning is the development of transversal competences, which includes critical and innovative thinking, communication skills, intrapersonal skills, global citizenship, media and information literacy.

3. The freedom of cognition becomes an important factor in the knowledge acquisition process, leading to exploring available information and transforming it into the knowledge. As a result learning process accomplishes and the changes occur not only into a student, but he/she also gives a contribution to the knowledge society.

4. Only the presence of the information society cannot provide a productive learning environment as positive emotional environment is also required, the positive emotions encourage students to learn, while the negative can stop the progress of the learning process at all.

5. Within the case study carried out in the National debate tournament (November 16, 2016), the largest number of respondents admitted that through debating they have learnt how to express freely their opinion, argumentation skills, to speak in public, to cooperate, to be confident, to think critically, to research, etc. The biggest differences between men and women were found in the acquired listening skills, the ability to find information and argumentation skills.

6. The competences gained through debating help students to solve real-life problems. They promote communication skills in various situations, selfconfidence and knowledge about real-life problems. Debating contributes to development of transversal competences, which have gained importance in the 21 st century.

\section{References}

Benavides, F., Dumont, H., \& Istance, D. (2012). The Nature of Learning: Using Research to Inspire Practice. The Practitioner Guide. OECD Publications. Available: https://www.oecd.org/edu/ceri/50300814.pdf

Bookchin, M. (1982). The ecology of freedom. Palo Alto: Cheshire Books.

Brikše, I. (2006). Informācijas vide Latvijā 21. gadsimta sākums. Rīga: Zinātne. 
Alīda Samuseviča, Maija Ročāne. Student’s gains of debating in the productive learning process

Edwards, J. (2007). Freedom of the Will. Grand Rapids, MI: Christian Classics Ethereal Library. Available: http://www.ntslibrary.com/PDF\%20Books/Jonathan\%20Edwards\% 20Freedom\%20of\%20the\%20Will.pdf

European Commission. (2007). Key Competences for Lifelong Learning - A European Framework. Belgium. Available: https://www.britishcouncil.org/sites/default/files/ youth-in-action-keycomp-en.pdf

European Commission. (2007). Key Data on Education in Europe 2012. Brussels: Education, Audiovisual and Culture Executive Agency. Available: http://eacea.ec.europa.eu/ education/eurydice/documents/key_data_series/134EN.pdf

Fisher, J. M. (2005). Freedom and foreknowledge. (pp. 280-290) In: Critical Concepts in Philosophy. London \& New York: Routledege.

Fullan, M., \& Langworthy, M. (2014). A Rich Seam: How New Pedagogies Find Deep Learning. London: Pearson.

Latvijas Republikas Izglītības un zinātnes ministrija. (2013). Izglìtības attīstības pamatnostādnes 2014. - 2020. gadam. Rīga.

Martinsone, K. (1999). Emotional attitude toward self as an identity component. (pp. 51-58) In: Identity and self-esteem. Rīga: Mācību apgads NT.

Martin-Kniep, M. G., \& Picone Zocchia, J. (2009). Changing the way you teach: Improving the way students learn. Alexandria, VA: Association for Supervision and Curriculum Development.

Marton, F., \& Booth, S. (2009). Learning and Awareness. London \& New York: Routledge.

O`Connor, T. (2005). Free Will: Concepts and challenges. (pp. 7-22) In: Critical Concepts in Philosophy. London \& New York: Routledege.

Oganisjana, K. (2015). Starpdisciplinārās mācības uzṇēmības un uzṇēmējspējas veicināšanai. Rīga: Latvijas Universitāte.

Oshana, M. (1997). Ascriptions of responsibility. (pp. 71-83) In: American Philosophical Quarterly. Vol. 34, No. 1. Illinois: University of Illinois Press.

Peterssen, W. H. (1983). Lehrbuch Allgemeine Didaktik. München: Ehrenwirth.

Savin-Baden, M., \& Major, C. H. (2004). Foundations of Problem-Based Learning. Berkshire: Society for Research into Higher Education and Open University Press.

Steiner, R. (1918). The philosophy of freedom. Available: http://wn.rsarchive.org/Books/ GA004/English/RSP1964/GA004_index.html

UNESCO (2005). Towards Knowledge Societies. Paris. Available: http://unesdoc.unesco.org/ images/0014/001418/141843e.pdf

UNESCO (2015). Transversal Skills in TVET: Policy Implications. Asia-Pacific Education System Review Series No 8. Bangkok. Available: http://unesdoc.unesco.org/ images/0023/002347/234738E.pdf

Veide, M. (1998). Garīgās brīvības veidošanās pusaudžiem skolās. Rīga: Latvijas Universitāte 132 lpp.

Zull, J. E. (2004). The Art of Changing the Brain. (pp. 68-72) In: Educational Leadership. Vol. 62, No. 1.

Тутушкина, М. (2001). Психология личной и обыденной жсизни. Санкт-Петербург: Дидактика Плюс. 